\title{
International fund fosters cross-border Irish research
}

Munich. Neatly timed to demonstrate the general benefits of the Anglo-Irish peace initiative, three major cross-border research programmes have just been launched to promote collaboration between scientists from the north and south of Ireland, who have tended to be isolated from each other.

The programmes are financed by the International Fund for Ireland (IFI), set up by the Irish and British governments under the Anglo-Irish peace agreement of 1986 to promote political stability by boosting the economies on both sides of the border.

The fund distributes a total of I£ 20 million (US\$32) a year, provided by the United States, Canada, New Zealand and the European Union (EU), to economically disadvantaged areas in Northern Ireland and to regions close to each side of the border.

Science is one of the fund's beneficiaries and I£2.5 million has been made available for research between 1995 and 1997. The money must be matched by local funds and will support three programmes: biotechnology; biomedical and environmental sensors; and rapid product development technology, which allows plastic models of any new product to be manufactured within hours.

The biotechnology programme is intended to raise the level of biotechnology in the north, where research is fragmented between small and relatively isolated groups, compared to that in the south. Through the activities of BioResearch Ireland, a government-backed contract research organization with five universitybased centres, southern Ireland has developed a strong biotechnology infrastructure.

The IFI programme will create an analogous centre, known as the Centre for Innovation in Biotechnology (CIB), at two sites in Northern Ireland: Queen's University in Belfast and the University of Ulster at Coleraine. In addition, it will have an important strategic component, in that the programme will fund a detailed analysis of the strengths and weaknesses of biotechnology on both sides of the border, and an extension of BioResearch Ireland's database of biotechnology resources in Ireland to include the six counties of the north.

The new centre hopes to raise a further If1 million in industrial or EU funds during the three years it is supported by IFI, and then to survive chiefly on industrial contracts. Its first two scientific programmes, geared to exploiting local resources and industries, are intended to demonstrate the feasibility of this idea.

One, based at Queen's University, is designed to help mushroom farmers. Ireland has a successful mushroom industry on both sides of the border that uses waste from the poultry industry, treated at central composters, to supply smallholders with growing medium for mushrooms.

In collaboration with the National Agricultural and Veterinary Biotechnology Centre in Dublin, the team at Queen's will study how to control outbreaks of disease which can lead to the destruction of crops and the need to quarantine land.

The research will involve monitoring the spread of outbreaks, studying the biochemistry of pathogenic organisms and developing diagnostic tests, based on DNA probes, to identify pathogens. "Pathogenic organisms don't recognize national borders", says Fred Wright, who heads the project at Queen's University. $\mathrm{He}$ argues that scientists should take the same attitude.

The second project exploits the spent fermentation waste from the brewing industry in the north to produce novel diagnostic products. Scientists at Coleraine will isolate and purify enzymes from the waste which they will then supply to BioResearch Ireland's laboratories in Galway.

The IFI biosensors programme has similar ambitions to the biotechnology programme. It combines the expertise of scientists from Queen's University and the

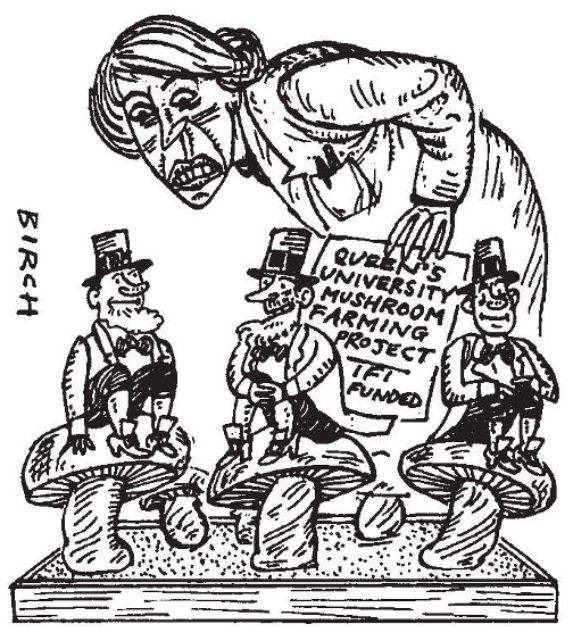

University of Ulster in the north, and others from Dublin City University and the University of Limerick in the south.

Dublin City University already has considerable expertise in developing biosensors, including a sensor that can be used to measure blood sugars (glucose and lactose) in real-time. Dermot Diamond, one of the researchers who developed the sensor, says that the IFI programme will help to overcome the previous lack of communication.

"We may not hear what our colleagues [in the north] are doing, even though Belfast is not many miles away," says Diamond.

Alison Abbott

\section{Confident companies foresee biotechnology expansion in Europe}

London. In contrast to the down-turn in the US biotechnology industry, Europe's biotechnology companies are continuing to expand and remain optimistic about their future prospects, according to an upbeat report that has just been published in London by the management consultants Ernst and Young.

Analysis of the response to a questionnaire from almost 200 companies using various types of biotechnology suggested that overall employment in the sector is expected to grow steadily, at an overall rate of about one per cent a year. Among smaller biotechnology companies, job prospects are even better, with an expected annual growth rate of six per cent.

Even in Germany, says the report, public opposition to biotechnology appears to be waning as awareness grows of the potential medical benefits of new biomedical technologies. This is reflected in moves by various regional authorities to support the growth of small biotechnology.

"European biotech companies are clearly more optimistic about the near-term future than are their US counterparts," says Bill Pike of Ernst and Young's National Biotechnology Office in Cambridge, England. Pike is one of the main authors of the second survey of the European biotechnology industry that was carried out in parallel to a similar survey conducted annually in the United States, and is based on responses to a questionnaire sent to more than 400 companies.

It points out that the 1995 US survey revealed that ten per cent of respondents indicated that one of their most significant actions over the next two years will be to lay off large numbers of employees. "No chief executive officer responding to our European survey anticipated such an action," the report states.

Challenging another widespread impression, the report points out that opposition to biotechnology in Germany is limited to a relatively few number of highly publicized protest activities. In contrast, in points out that a number of states - including Bavaria, Baden Württemberg and Rheinland Pfalz - have established biotech 'incubators' to help small companies get established.

The report describes this "new-found German enthusiasm for biotech" as "probably one of the most significant and encouraging changes taking place in Europe". It points out that Germany could become "a significant target for foreign companies hoping to take advantage of [its] excellent science base - and that "the idea that companies would choose to establish themselves in Germany was unheard of just a few years ago".

David Dickson 